\title{
Production of a monoclonal antibody specific to the genus Trichoderma and closely related fungi, and its use to detect Trichoderma spp. in naturally infested composts
}

\author{
Christopher R. Thornton, Dennis Pitt, Gavin E. Wakley \\ and Nicholas J. Talbot
}

Washington Singer Laboratories, School of Biological Sciences, University of Exeter, Perry Road, Exeter, Devon EX4 4QG, UK
Author for correspondence: Christopher R. Thornton. Tel: +44 1392 264653. Fax: +44 1392264668. e-mail: C.R.Thornton@ex.ac.uk

Studies of the interactions between hyperparasitic fungi and their hosts are severely hampered by the absence of methods that allow the unambiguous identification of individual genera in complex environments that contain mixed populations of fungi, such as soil or compost. This study details the development of a monoclonal antibody (MF2) that allows the detection and recovery of Trichoderma spp. in naturally infested composts, and the visualization of hyperparasitic strains of Trichoderma during antagonistic interactions with their hosts. Murine monoclonal antibody MF2, of immunoglobulin class M (IgM), was raised against a protein epitope of a glycoprotein antigen(s) specific for species of the genus Trichoderma and for the closely related fungi Gliocladium viride, Hypomyces chrysospermus, Sphaerostilbella spp. and Hypocrea spp. MF2 did not react with antigens from Gliocladium catenulatum, Gliocladium roseum, Nectria ochroleuca and Clonostachys spp., nor with a range of unrelated soil- and compost-borne fungi. Extracellular production of the MF2 antigen was constitutive. Westernblotting analysis showed that MF2 bound to a ladder of proteins with apparent molecular masses in the range 35-200 kDa. Immunofluorescence studies showed that MF2 bound strongly to the cell walls of hyphae and phialides and the intercalary and terminal chlamydospores of Trichoderma spp., whereas immunogold electron microscopy revealed strong binding of MF2 to the cell walls and septa of hyphae and to the cell walls of phialoconidia. In immunofluorescence studies of dual cultures of Trichoderma and Rhizoctonia solani, only the cell walls of the hyperparasite, which coiled around the host, were stained by MF2. The specificity of MF2 enabled the development of a combined baiting-ELISA technique for the detection of Trichoderma spp. in naturally infested composts. The specificity of this technique was confirmed by phylogenetic analysis based on sequences of the ITS1-5.8S-ITS2 rRNA-encoding regions of the isolates.

Keywords: Gliocladium, $\beta$-1,3-glucanase, glucoamylase, ITS region

\section{INTRODUCTION}

Species of the genus Trichoderma Persoon are ubiquitous soil- and compost-borne saprotrophs, which have been exploited in the commercial production of enzymes

Abbreviations: IF, immunofluorescence; ITS, internally transcribed spacer; PAS, periodic acid Schiff.
(Cullen \& Kersten, 1992) and in the biological control of plant diseases caused by economically important plant pathogens such as Rhizoctonia solani Kuhn and Pythium ultimum Trow (Papavizas, 1985; Whipps, 1997). Trichoderma spp. are the causative agent of disease in commercially produced mushrooms (Seaby, 1987), and have been identified as causal agents of disease in immunosuppressed and transplant patients (Jacobs et 
al., 1992; Loeppke et al., 1983; Richter et al., 1999; Tanis et al., 1995).

Despite the enormous potential of Trichoderma spp. to control soil-borne plant pathogens, their widespread use as biological control agents has not been fully realized. One reason for this lack of utilization can be attributed to the absence, to date, of accurate and sensitive methods for the rapid detection and visualization of Trichoderma spp. in complex environments that contain mixed populations of fungi, such as soil or compost. Conventional methods for detecting Trichoderma propagules, which employ plate-enrichment techniques, do not always satisfactorily differentiate between Trichoderma spp. and contaminant fungi in mixed populations. Furthermore, these assays are labour intensive, cumbersome and require considerable taxonomic expertise. The mutation of Trichoderma strains to benomyl tolerance and the transformation of Trichoderma strains with $\beta$-glucuronidase- and greenfluorescent-protein-encoding genes have provided useful tools for ecological studies in the rhizosphere and bulk soil, but these studies are restricted to individual fungicide-tolerant or recombinant isolates (Ahmad \& Baker, 1988; Pe'er et al., 1991; Bae \& Knudsen, 2000; Green \& Jensen, 1995; Thrane et al., 1995).

The development of a specific and sensitive assay for the detection and visualization of naturally occurring Trichoderma populations would enable a more accurate determination to be made of the presence of this important fungal genus in naturally infested soil and compost samples, and would facilitate studies of the spread and survival of Trichoderma populations artificially introduced into soils or composts. Furthermore, a procedure that also allowed the subsequent recovery of strains would aid the identification of isolates with potentially exploitable hyperparasitic activities.

Hybridoma technology allows the production of monoclonal antibodies (mAbs) that are specific to individual genera, species or even isolates of fungi (Dewey \& Thornton, 1995). mAbs have been used successfully to detect, quantify and visualize the saprotrophic growth of pathogens, such as Rhizoctonia solani, in artificially and naturally infested soils (Dewey et al., 1996; Otten et al., 1997; Thornton et al., 1993, 1999), and have been used to quantify the effects of the hyperparasite Trichoderma harzianum on the saprotrophic growth dynamics of Rhizoctonia solani in compost-based systems (Thornton \& Gilligan, 1999). These studies showed that the most appropriate antigens for the detection of fungi in soils and composts were those that were extracellular and that were constitutively expressed or could be induced. Studies of extracellular antigen (enzyme) production in Trichoderma spp. have shown that the enzyme $\beta$-1,3-glucanase presents an ideal candidate for the production of mAbs specific to this genus. The enzyme is extracellular and its production is constitutive or semi-constitutive (Bull \& Chesters, 1966; Elad et al., 1982; Ramot et al., 2000).

In this study, we used a commercial $\beta$-1,3-glucanase preparation to develop a murine hybridoma cell line secreting $\mathrm{mAbs}$ specific for Trichoderma spp. and for fungi closely related to them. Using the mAb MF2, we show how the antigen can be used as a molecular marker for the detection and recovery of Trichoderma spp. in naturally infested composts.

\section{METHODS}

Fungal culture. Unless indicated otherwise, fungi were grown on Vogel's glucose agar (VGA) (Sandhu \& Kalra, 1982) either in Petri dishes or on slants at $23^{\circ} \mathrm{C}$, with the exceptions of Phytophthora fragariae (grown on bean agar at $4{ }^{\circ} \mathrm{C}$ ), Armillaria spp. and Phytophthora erythroseptica (grown on $2 \%, \mathrm{w} / \mathrm{v}$, malt extract agar at $23^{\circ} \mathrm{C}$ ) and Phytophthora cactorum (grown on V8 agar, $\mathrm{pH} 7 \cdot 0$, at $23^{\circ} \mathrm{C}$ ).

Development of the mAb, preparation of the immunogen, and the immunization regime. Preparations of Trichoderma $\beta$-1,3-glucanase were obtained commercially. These included a chromatographically purified enzyme preparation from ICN (198904), a crude preparation from Sigma (L5272) and Glucanex from Novo Nordisk Fermentation. Preliminary examination of these preparations by PAGE and staining with Coomassie brilliant blue or the periodic acid Schiff (PAS) reaction (Carlsson, 1993) showed the chromatographically purified preparation from ICN to be composed of glycoprotein(s) of high molecular mass, consistent with the constitutive $200 \mathrm{kDa} \beta$-1,3-glucanase $(\mathrm{G} \beta$-1,3-200) recently described by Ramot et al. (2000). Consequently, ICN 198904 was chosen for hybridoma production in an attempt to raise $\mathrm{mAbs}$ specific to a constitutive Trichoderma antigen. It is hereafter referred to as the immunogen.

Twenty-five units of lyophilized immunogen were reconstituted in $1 \mathrm{ml}$ of PBS $(0.8 \% \mathrm{NaCl} ; 0.02 \% \mathrm{KCl} ; 0.115 \%$ $\left.\mathrm{Na}_{2} \mathrm{HPO}_{4} ; 0.02 \% \quad \mathrm{KH}_{2} \mathrm{PO}_{4} ; \mathrm{pH} 7 \cdot 2\right)$. Three 6-week-old $\mathrm{BALB} / \mathrm{c}$ female white mice were each given four intraperitoneal injections $(300 \mu \mathrm{l}$ per injection) of fresh immunogen at 2 week intervals. A single booster injection was administered 5 days before fusion.

Production and screening of hybridomas and the determination of antibody specificities. Hybridoma cells were produced by the method described by Dewey (1992) and the supernatants were screened by ELISA. Primary screening was performed against the immunogen. Twenty-five units of lyophilized protein were reconstituted in $30 \mathrm{ml}$ PBS. Secondary screening for specificity was performed against surface washings from slant cultures of fungal isolates grown on VGA at $23^{\circ} \mathrm{C}$. Cultures were washed with $1 \mathrm{ml}$ of PBS and the surface washings were centrifuged in $1.5 \mathrm{ml}$ microcentrifuge tubes at $12000 \mathrm{~g}$ for $10 \mathrm{~min}$ to remove cell debris; the resulting supernatants were diluted 10-fold in fresh PBS. Microtitre wells arranged in strips (Labsystems Oy) were coated overnight at $4{ }^{\circ} \mathrm{C}$ with $50 \mu$ l volumes of diluted immunogen or with $1 / 10$ surface washings. The wells were washed four times with PBST (PBS + 0.05\%, v/v, Tween 20; Sigma) and once each with PBS and $\mathrm{dH}_{2} \mathrm{O}$. They were then air-dried at $23{ }^{\circ} \mathrm{C}$ under a laminar-flow hood. The strips were stored in sealed plastic bags at $4{ }^{\circ} \mathrm{C}$ in preparation for screening of the hybridoma supernatants by ELISA, as described below.

ELISA. Wells containing immobilized surface antigens were incubated with hybridoma supernatant for $1 \mathrm{~h}$, followed by incubation with either a goat-anti-mouse polyvalent (IgG, IgA and $\operatorname{Ig} M$ ) peroxidase conjugate (diluted 1 in 1000; Sigma) or a goat-anti-mouse IgM ( $\mu$-chain specific) peroxidase conjugate 
(diluted 1 in 5000; Sigma) for a further 1 h. Bound antibody was visualized by incubating the wells with tetramethyl benzidine substrate solution for $30 \mathrm{~min}$; reactions were stopped by the addition of $3 \mathrm{M} \mathrm{H}_{2} \mathrm{SO}_{4}$. Absorbance values were determined at $450 \mathrm{~nm}$ with an MRX automated microplate reader (Dynex Technologies). Wells were given four 5 min rinses with PBST between incubations. Working volumes were $50 \mu \mathrm{l}$ per well, and control wells were incubated with tissue culture medium containing $10 \%(\mathrm{v} / \mathrm{v})$ fetal calf serum. All incubation steps were performed at $23{ }^{\circ} \mathrm{C}$ in sealed plastic bags.

Determination of the immunoglobulin subclass and the cloning procedure. The immunoglobulin subclass of the $\mathrm{mAbs}$ was determined with a commercial mouse mAb isotyping kit, according to the manufacturer's instructions (Sigma). Hybridoma cell lines were cloned by limiting dilution and were grown in bulk in a non-selective medium. The cells lines were preserved by slowly freezing them in fetal bovine serum/dimethyl sulfoxide $(92: 8, \mathrm{v} / \mathrm{v})$ and storing them in liquid nitrogen.

Epitope characterization by protease digestion. Microtitre wells containing immobilized immunogen $(50 \mu \mathrm{l})$ were incubated with $0 \cdot 25$ U Pronase well ${ }^{-1}$ (Protease XIV) (Sigma) or with trypsin (Sigma) solution $\left(1 \mathrm{mg} \mathrm{ml}^{-1}\right.$ in PBS) at $37^{\circ} \mathrm{C}$ or $4^{\circ} \mathrm{C}$ for $5 \mathrm{~h}$. The wells were then washed three times with PBS. Wells incubated with trypsin were treated for $10 \mathrm{~min}$ with a $0.1 \mathrm{mg} \mathrm{ml}^{-1}$ solution of trypsin inhibitor (Sigma) and were given three more washes with PBS. Controls received PBS without Pronase or trypsin and inhibitor, but were otherwise treated similar to the test samples. Six replicates were performed for each treatment. The wells were assayed by ELISA with MF2, as described above.

Epitope characterization by periodate oxidation. Immobilized immunogen was treated with $50 \mu$ l of sodium mperiodate $\left(20 \mathrm{mM} \mathrm{NaIO}_{4}\right.$ in $50 \mathrm{mM}$ sodium acetate buffer, pH 4.5) (Sigma), whereas control wells received only buffer. After incubation for the appropriate time period in darkness at $4{ }^{\circ} \mathrm{C}$, wells were washed three times with PBS and assayed by ELISA with MF2, as described. Four replicates were performed for each treatment.

Growth of mycelium and antigen production on laminarin and glucose. Glucose or laminarin (Sigma) were added (0.5 g) to $50 \mathrm{ml}$ of Vogel's medium (VM) (Sandhu \& Kalra, 1982), which had been adjusted to $\mathrm{pH} 5.5$ with $1 \mathrm{M} \mathrm{HCl}$ in separate $250 \mathrm{ml}$ flasks. The media were then sterilized by autoclaving at $121{ }^{\circ} \mathrm{C}$ for $15 \mathrm{~min}$. The flasks were inoculated with three plugs ( $3 \mathrm{~mm}$ diameter) of mycelium taken from the leading edge of 4-day-old VGA cultures of Trichoderma koningii isolate TLS grown at $25^{\circ} \mathrm{C}$. The flasks were incubated as shake cultures at $25^{\circ} \mathrm{C}$, and at 3 day intervals $100 \mu$ of culture fluid was removed from each flask. Culture fluids were centrifuged for $5 \mathrm{~min}$ at $12000 \mathrm{~g}$ and $50 \mu \mathrm{l}$ samples were transferred to microtitre wells. There were three replicates for each treatment and the experiment was performed twice. Absorbance values in ELISA were converted to units of protein equivalents by using standard calibration curves of immunogen, prepared from doubling dilutions of a PBS solution of the immunogen in microtitre wells. After immobilization and washing of the samples, wells were assayed by ELISA with MF2 or with tissue culture medium only, as described above. An ELISA of calibration curves was performed on the same day as the assay of the culture extracts, to eliminate day-to-day variability in results (Otten et al., 1997). The dry weights of mycelial mats were obtained by filtering the contents of each flask through weighed Whatman filter paper no. 1 and drying the collected material to constant weight at $80^{\circ} \mathrm{C}$.
In a separate experiment, glucose and laminarin cultures were prepared as described above and were incubated for 5 days under the same conditions. Mycelia were removed by filtration and the culture filtrates were immediately precipitated with $80 \%$ acetone. The precipitate was recovered by centrifugation at $27000 \mathrm{~g}$ for $45 \mathrm{~min}$ at $4{ }^{\circ} \mathrm{C}$. The concentrated samples were resuspended in $\mathrm{dH}_{2} \mathrm{O}$, snap-frozen in liquid $\mathrm{N}_{2}$ and lyophilized. Lyophilized material was used as a source of $\beta$-1,3glucanase. There were two replicates for each treatment and the experiment was performed twice. Samples were assayed for $\beta$-1,3-glucanase and amylase activities, as described below. Protein concentrations were determined using the Bio-Rad Bradford protein assay, with BSA (Sigma) as the standard.

Assay of $\beta$-1,3-glucanase activity and amylase activity. The standard assay mixture (vol. $500 \mu \mathrm{l}$ ) contained protein concentrate reconstituted in $50 \mathrm{mM}$ sodium acetate buffer $(\mathrm{pH} 5.0)$ and $5 \mathrm{mg}$ of laminarin or soluble potato starch (Sigma) per ml. Reaction mixtures were incubated for $1 \mathrm{~h}$ at $50{ }^{\circ} \mathrm{C}$. The reactions were stopped by boiling for $5 \mathrm{~min}$, and the production of reducing sugars (glucose) was determined by using a commercial glucose oxidase assay (Sigma). An enzymic unit was defined as the amount of enzyme that catalysed the release of $1 \mathrm{mg}$ glucose $(\mathrm{mg} \text { protein })^{-1} \mathrm{~min}^{-1}$. Standards for glucose, as well as for enzyme and substrate blanks, were also included.

PAGE and Western blotting. PAGE was carried out by using the system of Laemmli (1970), with 4-20\% gradient polyacrylamide gels (Bio-Rad) under denaturing conditions. Denatured samples were prepared by heating at $95^{\circ} \mathrm{C}$ for $10 \mathrm{~min}$ in the presence of $\beta$-mercaptoethanol, prior to gel loading. Proteins were separated for $1.5 \mathrm{~h}$ at room temperature $(165 \mathrm{~V})$. Prestained, broad-range markers (Bio-Rad) were used for molecular mass determinations. Gels were stained for total protein with Coomassie brilliant blue or by the carbohydrate-specific PAS reaction.

For Western blots, separated proteins were electrophoretically transferred to a PVDF membrane (Immuno-Blot PVDF; BioRad). Membranes were washed three times with PBS and then blocked for $16 \mathrm{~h}$ at $4{ }^{\circ} \mathrm{C}$ with PBS containing $1 \%(\mathrm{w} / \mathrm{v})$ BSA. Blocked membranes were incubated with mAb supernatant diluted 1 in 2 with PBS containing $0.5 \%$ BSA (PBSA) for $2 \mathrm{~h}$ at $23{ }^{\circ} \mathrm{C}$. After washing three times with PBS, membranes were incubated for $1 \mathrm{~h}$ with a goat-anti-mouse $\operatorname{IgM}$ ( $\mu$-chain specific) alkaline phosphatase conjugate (Sigma) diluted 1 in 15000 in PBSA. Membranes were washed twice with PBS and once with PBST. Bound antibody was visualized by incubation in substrate solution (Thornton et al., 1993). Reactions were stopped by immersing the membranes in $\mathrm{dH}_{2} \mathrm{O}$; the membranes were then air-dried between sheets of Whatman filter paper. Labelling of the glycosylated proteins immobilized on the PVDF membranes was performed using a commercial glycoprotein detection kit, according to the manufacturer's instructions (Bio-Rad).

$\mathrm{N}$-terminal sequence analysis. $\mathrm{N}$-terminal sequence analysis of the antigen was carried out by Alta Bioscience with a PE Biosystems 473A automatic protein sequencer. The gapped BLAST program (version 2.0; Altschul et al., 1997) was used to compare the amino acid sequences we generated with those contained within databases held at the NCBI website (http:// www.ncbi.nlm.nih.gov).

Indirect immunofluorescence (IF). Cultures of Trichoderma isolate CST1, Trichoderma isolate S-B2 and Trichoderma virens isolate JI3-A8 were grown for 4 days at $25^{\circ} \mathrm{C}$ on slides embedded in VGA, either in pure culture or in dual culture with Rhizoctonia solani isolate AB1. The slides were air-dried and fixed according to Dewey (1992). Wells were incubated 
Table 1. Details of ELISA results for fungal isolates screened in this study

The results presented here are representative of three replicate experiments.

\begin{tabular}{|c|c|c|c|}
\hline Organism & Isolate no.* & Source $†$ & $A_{450} \neq$ \\
\hline Armillaria mellea & AM1 & D. Farley & $0 \cdot 023$ \\
\hline Aspergillus flavus & 91856ii & IMI & $0 \cdot 002$ \\
\hline Aspergillus fumigatus & 181 & J. Webster & $0 \cdot 000$ \\
\hline Aspergillus oryzae & 29 & J. Webster & $0 \cdot 010$ \\
\hline Botryotrichum piluliferum & 43 & J. Webster & $0 \cdot 000$ \\
\hline Botrytis cinerea & $\mathrm{R} 2 / 239$ & J. Webster & $0 \cdot 005$ \\
\hline Botrytis cinerea & WCC-A8 & C.R. Thornton & $0 \cdot 001$ \\
\hline Ceratobasidium cornigerum & 34054 & ATCC & $0 \cdot 000$ \\
\hline Chaetomium indicum & 182 & J. Webster & $0 \cdot 000$ \\
\hline Clonostachys rosea & 710.86 & CBS & $0 \cdot 007$ \\
\hline Clonostachys solani & 102418 & CBS & $0 \cdot 008$ \\
\hline Curvularia clavata & 239 & J. Webster & $0 \cdot 001$ \\
\hline Curvularia leonensis & 236 & J. Webster & $0 \cdot 000$ \\
\hline Fusarium culmorum & HBC-A3 & C.R. Thornton & $0 \cdot 022$ \\
\hline Fusarium oxysporum f.sp. pisi & 260.50 & CBS & $0 \cdot 008$ \\
\hline Fusarium solani f.sp. pisi & 231.34 & CBS & $0 \cdot 002$ \\
\hline Gaeumannomyces graminis var. avenae & GP36 & G.L. Bateman & $0 \cdot 000$ \\
\hline Gaeumannomyces graminis var. graminis & D1 & C.R. Thornton & $0 \cdot 000$ \\
\hline Gaeumannomyces graminis var. tritici & $16 / 8$ & G.L. Bateman & $0 \cdot 001$ \\
\hline Gliocladium catenulatum & 529.80 & CBS & $0 \cdot 044$ \\
\hline Gliocladium roseum & 710.86 & CBS & $0 \cdot 021$ \\
\hline Gliocladium viride & 228.48 & CBS & $1 \cdot 189$ \\
\hline Hypocrea gelatinosa & 254.62 & CBS & $1 \cdot 350$ \\
\hline Hypocrea pallida & 668.75 & CBS & $0 \cdot 395$ \\
\hline Hypocrea lutea & 658.70 & CBS & $1 \cdot 316$ \\
\hline Hypocrea rufa & 435.95 & CBS & $1 \cdot 272$ \\
\hline Hypomyces chrysospermus & 140.23 & CBS & $1 \cdot 466$ \\
\hline Mucor plumbeus & 96 & J. Webster & $0 \cdot 000$ \\
\hline Mucor racemosus & 93 & J. Webster & $0 \cdot 003$ \\
\hline Nectria ochroleuca & 245.78 & CBS & $0 \cdot 011$ \\
\hline Penicillium expansum & 106 & J. Webster & $0 \cdot 005$ \\
\hline Penicillium sp. & HBC-A9 & C.R. Thornton & $0 \cdot 006$ \\
\hline Phytophthora cactorum & - & D. Pitt & $0 \cdot 003$ \\
\hline Phytophthora erythroseptica & - & D. Pitt & $0 \cdot 002$ \\
\hline Phytophthora fragariae & - & D. Pitt & $0 \cdot 000$ \\
\hline Pythium aphanidermatum & WQ4 & C.R. Thornton & $0 \cdot 008$ \\
\hline Pythium debaryanum & - & D. Pitt & $0 \cdot 002$ \\
\hline Pythium irregulare & 287.31 & CBS & $0 \cdot 011$ \\
\hline Pythium oligandrum & PO1 & C.R. Thornton & $0 \cdot 003$ \\
\hline Pythium spinosum & FHS12 & C.R. Thornton & $0 \cdot 004$ \\
\hline Pythium sylvaticum & 227.68 & CBS & $0 \cdot 014$ \\
\hline Pythium ultimum & PU132 & D. Pitt & $0 \cdot 001$ \\
\hline Rhizoctonia cerealis & SL4/2 & P. Nicholson & $0 \cdot 003$ \\
\hline Rhizoctonia oryzae & 376335 & IMI & $0 \cdot 004$ \\
\hline Rhizoctonia oryzae-sativae & 62599 & IMI & $0 \cdot 005$ \\
\hline \multicolumn{4}{|l|}{ Rhizoctonia solani anastomosis group } \\
\hline 1 & 01R01 & IPO & $0 \cdot 001$ \\
\hline 2.1 & 21R01 & IPO & $0 \cdot 000$ \\
\hline 2.2 & 22R11 & IPO & $0 \cdot 002$ \\
\hline 3 & 03R01 & IPO & $0 \cdot 000$ \\
\hline 4 & $\mathrm{AB} 1$ & C.R. Thornton & $0 \cdot 003$ \\
\hline 5 & 303159 & IMI & $0 \cdot 000$ \\
\hline 7 & 303161 & IMI & $0 \cdot 000$ \\
\hline Rhizopus sexualis & - & C.R. Thornton & $0 \cdot 000$ \\
\hline Rhizopus stolonifer & - & C.R. Thornton & $0 \cdot 001$ \\
\hline Rhizopus sp. & S-A4 & C.R. Thornton & $0 \cdot 005$ \\
\hline Sordaria fimicola & 152 & J. Webster & $0 \cdot 002$ \\
\hline Sphaerostilbella aureonitens & 93.2121 & CBS & $1 \cdot 214$ \\
\hline Sphaerostilbella lutea & 225.85 & CBS & $0 \cdot 005$ \\
\hline
\end{tabular}


Table 1 (cont.)

\begin{tabular}{|c|c|c|c|}
\hline Organism & Isolate no.* & Source $†$ & $A_{450} \neq$ \\
\hline Sphaerostilbella novaezelandiae & 93.0907 & CBS & $1 \cdot 093$ \\
\hline Syncephalastrum racemosum & 155 & J. Webster & $0 \cdot 001$ \\
\hline Thamnidium elegans & 161 & J. Webster & $0 \cdot 000$ \\
\hline Trichoderma aureoviride & - & D. Pitt & $0 \cdot 645$ \\
\hline Trichoderma hamatum & 091 & D. Pitt & $0 \cdot 903$ \\
\hline Trichoderma hamatum & $G O D-B 4 \$$ & C.R. Thornton & $0 \cdot 920$ \\
\hline Trichoderma hamatum & $G O D-B 7 \$$ & C.R. Thornton & $0 \cdot 934$ \\
\hline Trichoderma harzianum & $L E V-A 8 \mathbb{S}$ & C.R. Thornton & $1 \cdot 132$ \\
\hline Trichoderma harzianum & $L E V-B 7 \mathbb{S}$ & C.R. Thornton & $1 \cdot 067$ \\
\hline Trichoderma harzianum & - & P. Mills & $1 \cdot 251$ \\
\hline Trichoderma harzianum & - & D. Pitt & $1 \cdot 347$ \\
\hline Trichoderma harzianum & 134 & D. Pitt & $1 \cdot 340$ \\
\hline Trichoderma harzianum & 136 & D. Pitt & $1 \cdot 117$ \\
\hline Trichoderma harzianum & T95 & R. Baker & $1 \cdot 380$ \\
\hline Trichoderma koningii & TLS $\mathbb{S}$ & C.R. Thornton & $1 \cdot 261$ \\
\hline Trichoderma koningii & F5 & D. Pitt & $1 \cdot 305$ \\
\hline Trichoderma koningii & F10 & D. Pitt & $1 \cdot 281$ \\
\hline Trichoderma koningii & F14 & D. Pitt & 1.097 \\
\hline Trichoderma koningii & F16 & D. Pitt & $1 \cdot 099$ \\
\hline Trichoderma koningii & F17 & D. Pitt & $1 \cdot 358$ \\
\hline Trichoderma koningii & F62 & D. Pitt & $1 \cdot 490$ \\
\hline Trichoderma longibrachiatum & - & P. Mills & $1 \cdot 501$ \\
\hline Trichoderma longibrachiatum & 399.92 & CBS & $1 \cdot 106$ \\
\hline Trichoderma longibrachiatum (variant) & - & P. Mills & $1 \cdot 515$ \\
\hline Trichoderma piluliferum & 185209 & IMI & $1 \cdot 270$ \\
\hline Trichoderma reesei & - & P. Mills & $1 \cdot 446$ \\
\hline Trichoderma virens & 625.76 & CBS & $1 \cdot 090$ \\
\hline Trichoderma virens & $J I 3-A 8 S$ & C.R. Thornton & $1 \cdot 103$ \\
\hline Trichoderma virens & $J I 3-B 7 \mathbb{S}$ & C.R. Thornton & $1 \cdot 175$ \\
\hline Trichoderma viride & 089 & D. Pitt & $1 \cdot 523$ \\
\hline Trichoderma viride & - & P. Mills & $1 \cdot 334$ \\
\hline Trichoderma viride & $B U L-A 7 \mathbb{S}$ & C.R. Thornton & $1 \cdot 283$ \\
\hline Trichoderma viride & $H B C-B 4 \mathbb{S}$ & C.R. Thornton & $1 \cdot 308$ \\
\hline Trichoderma viride & $S-A 8 \mathbb{S}$ & C.R. Thornton & $0 \cdot 861$ \\
\hline Trichoderma viride & $S-B 3 \mathbb{S}$ & C.R. Thornton & $0 \cdot 952$ \\
\hline Trichoderma viride & $S-B 9 \mathbb{S}$ & C.R. Thornton & $1 \cdot 085$ \\
\hline Trichoderma sp. & $H B C-A 2$ & C.R. Thornton & 0.557 \\
\hline Trichoderma sp. & $S-B 2$ & C.R. Thornton & $0 \cdot 504$ \\
\hline Trichoderma sp. & CST1 & C.R. Thornton & $1 \cdot 213$ \\
\hline Trichothecium roseum & 168 & J. Webster & $0 \cdot 049$ \\
\hline Verticillium lecanil & 167 & J. Webster & $0 \cdot 043$ \\
\hline Verticillium sp. & HBC-A7 & C. R. Thornton & 0.009 \\
\hline Zygorrhynchus moelleri & 165 & J. Webster & $0 \cdot 000$ \\
\hline Zygorrhynchus moelleri & HBC-A1 & C. R. Thornton & 0.005 \\
\hline
\end{tabular}

*Isolates from commercial compost preparations: WCC, Westcountry; HBC, Homebase; S, Shamrock; GOD, Godwin; LEV, Levington; BUL, Bulrush; JI3, John Innes no. 3. Contaminating fungi recovered from baits of naturally infested composts are shown in bold. Trichoderma isolates recovered from baits of naturally infested composts are shown in italic.

†D. Farley, J. Webster, C. R. Thornton and D. Pitt, School of Biological Sciences, University of Exeter, UK; R. Baker, Dept Plant Pathology and Weed Science, Colorado State University, USA; IMI, International Mycology Institute, Egham, UK; ATCC, American Type Culture Collection, Manassas, VA, USA; CBS, Centraalbureau voor Schimmelcultures, The Netherlands; G. L. Bateman, AFRC Inst. Arable Crops Research Experimental Station, Harpenden, UK; P. Nicholson, John Innes Centre, Plant Science Research, Norwich, UK; IPO, Inst voor Planteziektenk, Onderzoek, Wageningen, The Netherlands; P. Mills, Horticultural Research Int., Wellesbourne, UK.

$\ddagger$ Values represent the means of replicated values corrected by subtraction of control values.

$\$$ Species identified in this study by sequencing of the ITS region of the rRNA-encoding genes. 
for $30 \mathrm{~min}$ with $50 \mu \mathrm{l}$ of MF2 or with $50 \mu \mathrm{l}$ of tissue culture medium only. Slides were washed three times with PBS with gentle agitation and were incubated for a further $30 \mathrm{~min}$ with a goat-anti-mouse polyvalent FITC conjugate (Sigma) diluted 1 in 40 in PBS. Slides were given three 5 min rinses with PBS, and the wells were overlaid with coverslips mounted with PBS/glycerol mounting medium (Sigma). Slides were examined with a Nikon microscope fitted with epifluorescence, using a UV excitation filter $(365 \mathrm{~nm})$ and an absorption filter $(420 \mathrm{~nm})$. All incubation steps were performed at $23{ }^{\circ} \mathrm{C}$ in a moist environment and the slides were stored at $4{ }^{\circ} \mathrm{C}$ in the dark in Petri dishes containing moistened Whatman filter paper no. 1 .

In a separate experiment, suspensions of washed phialoconidia from Trichoderma isolate CST1 and Trichoderma koningii isolate TLS were prepared from 4-week-old V8 agar Petri dish cultures. The washed cells were suspended in VM and transferred to the wells of multiwell slides. After incubation at $25^{\circ} \mathrm{C}$ for $16 \mathrm{~h}$, the slides were air-dried and fixed as described above. Antigen production by germinated and ungerminated spores was detected by IF as described.

Immunogold electron microscopy. Immunogold labelling was performed with mycelium and phialoconidia from Trichoderma koningii isolate TLS. Samples of mycelium were removed from 5-day-old liquid cultures of Trichoderma koningii isolate TLS grown in VM containing glucose. The mycelium was homogenized in $\mathrm{dH}_{2} \mathrm{O}$ and washed twice by repeated centrifugation and resuspension in $\mathrm{dH}_{2} \mathrm{O}$. Washed conidia were prepared as described. Mycelium and conidia were pelleted by centrifugation. The pellet was embedded at low temperature as described in Cole et al. (1998), except that the resin polymerization steps were carried out at $23^{\circ} \mathrm{C}$. Immunolabelling was carried out as described in Cole et al. (1998), with a goat-anti-mouse $20 \mathrm{~nm}$ gold conjugate (British Biocell International) as the secondary reporter molecule. Control grids were incubated with tissue culture medium instead of mAb supernatant, but were otherwise treated the same as the test grids.

Detection of Trichoderma spp. in naturally infested composts by baiting-ELISA, and setting of immunoassay thresholds. Commercial compost preparations were obtained from horticultural suppliers. Bulrush, Homebase, Levington and Shamrock composts consisted of sphagnum-moss peat, whereas Godwin compost was a mixture of sedge and sphagnum-moss peats. Westcountry compost was a greenwaste compost and composts John Innes No. 1, No. 2 and No. 3 consisted of peat compost and loam soil in varying proportions.

Detection of Trichoderma spp. in naturally infested composts using MF2 was performed by using a combined baiting-ELISA method, using the baiting technique described by Thornton et al. (1999). After incubation at $25^{\circ} \mathrm{C}$ for $72 \mathrm{~h}$, quinoa seed baits were removed from replicated baiting modules and placed individually into microtitre wells containing $50 \mu \mathrm{l}$ of $\mathrm{VM}$ containing $1 \mathrm{mg}$ glucose $\mathrm{ml}^{-1}$. The seeds were incubated for $7 \mathrm{~h}$ at $25^{\circ} \mathrm{C}$ to allow the production and immobilization of extracellular antigens. They were then transferred to Petri dishes containing medium for the recovery of Trichoderma isolates and other compost fungi (see below). Microtitre wells were washed and then assayed by ELISA using MF2 and a $\mu$ chain-specific peroxidase conjugate, as described above. Because the specific aim of this study was to examine the efficacy of the assay for detecting Trichoderma spp. in the presence of contaminating fungi, no assay of baits from sterilized composts was performed.

Thresholds for the detection of Trichoderma spp. by ELISA were established by plotting the frequencies of the absorbance values obtained in ELISAs for each compost against stepwise increments $(0 \cdot 100)$ in absorbance (Thornton et al., 1999).

Plate culture. Quinoa seed baits were transferred to $9 \mathrm{~cm}$ Petri dishes containing Trichoderma TME medium (Papavizas, 1982). The initial identification of putative isolates of Trichoderma spp. was based on the presence of phialides and phialoconidia. Putative Trichoderma isolates were further subcultured onto V8 agar and were classified to the species level by sequencing of their rRNA genes. Isolates of other fungi that commonly grew from the baits were also subcultured and identified on the basis of gross morphological characteristics and sporulation, using standard mycological texts (Domsch et al., 1980).

Confirmation of the isolation of Trichoderma spp. by analysis of the internally transcribed spacer (ITS) regions of the rRNAencoding gene unit. Representative isolates of fungi, detected and recovered from each of the naturally infested composts using MF2, were selected for further study on the basis of gross morphology, and their rRNA-encoding genes were amplified using a modification of the method described by Sreenivasaprasad et al. (1996). Primers ITS1 (5'-TCCGTAGGTGAACCTGCGG-3') and ITS4 (5'-TCCTCCGCTTATTGATATGC-3') were used to amplify the ITS1-5.8S-ITS2 region of the rRNA-encoding gene unit of each of the representative isolates. These primers were provided by Genosys and their sequences are based on those described by White et al. (1990). PCR of the the ITS1-5.8S-ITS2 region was performed as follows. Approximately 10-25 ng genomic DNA was added to a $0.2 \mathrm{ml}$ Eppendorf tube that had been prechilled to $-20{ }^{\circ} \mathrm{C}$ and which contained $0.05 \mu \mathrm{M}$ each primer, $2 \mathrm{mM}$ (each) dATP, dCTP, dGTP and dTTP (Pharmacia), $0.25 \mathrm{U}$ Taq polymerase (Promega), $1 \times$ Taq polymerase thermophillic buffer (Promega) and $2 \mathrm{mM} \mathrm{MgCl}_{2}$ (Promega). The final reaction volume was $25 \mu$ l. PCR amplification was performed in a thermal cycler (Hybaid Omn-E) with the following cycling conditions: $2 \mathrm{~min}$ at $94^{\circ} \mathrm{C}, 35$ cycles at $94{ }^{\circ} \mathrm{C}$ for $1 \mathrm{~min}, 55^{\circ} \mathrm{C}$ for $1 \mathrm{~min}$ and $72{ }^{\circ} \mathrm{C}$ for $3 \mathrm{~min}$, with a final extension of $5 \mathrm{~min}$ at $72{ }^{\circ} \mathrm{C}$. PCR products were separated using a $1.6 \%$ agarose gel. The DNA fragments obtained were purified from gels using a commercial kit (GENECLEAN; BIO 101), according to the manufacturer's instructions. Both strands of the entire ITS1-5.8S-ITS2 rRNA-encoding region were sequenced. Dye-labelled terminator cycle sequencing was performed by MWG Biotech AG (Ebersberg, Germany) and the results were processed using a Macintosh Power PC (7500/100). Double-stranded DNA sequences were aligned by using DNA Strider 1.1 (Marck, 1989) and Sequence Navigator 1.0.1 (Perkin Elmer). The gapped BLAST program (version 2.0; Altschul et al., 1997) was used to compare the nucleic acid sequences we generated with those contained within databases held at the NCBI website. Multiple-sequence alignments were performed using the MULTIALIGN program (http:// dot.imgen.bcm.tmc.edu:9331/multi-align/multi-align.html) (Thompson et al., 1994). Phylogenetic analysis was performed using the neighbour-joining method, as contained within the PAUP* (version 4.0; Swofford, 2000) package. The significance of each of the nodes within the phylogenetic tree was determined by bootstrap analysis, with 1000 replications. The ascomycete Echinodothis tuberiformis was used as the outgroup species for the phylogenetic tree shown in Fig. 7.

\section{RESULTS}

\section{Specificity of the hybridoma cell lines and isotyping}

A single fusion was performed and from this 434 hybridoma cell lines were screened for mAb produc- 
Table 2. Absorbance values from ELISAs (with MF2) for protease-treated and periodatetreated Trichoderma harzianum immunogen

Each value represents the mean of replicated values $\pm 95 \%$ confidence intervals corrected by subtraction of control values. The results are based on six replicated experiments.

\begin{tabular}{|c|c|c|c|c|}
\hline \multirow[t]{2}{*}{ Temperature $\left({ }^{\circ} \mathrm{C}\right)$} & \multicolumn{4}{|c|}{$A_{450}$} \\
\hline & Pronase & Control & Trypsin & Control \\
\hline 4 & $0 \cdot 533 \pm 0 \cdot 108$ & $1 \cdot 546 \pm 0 \cdot 057$ & $0 \cdot 861 \pm 0 \cdot 103$ & $1 \cdot 525 \pm 0.051$ \\
\hline 37 & $0 \cdot 375 \pm 0.075$ & $1.517 \pm 0.057$ & $0.669 \pm 0.098$ & $1 \cdot 519 \pm 0 \cdot 044$ \\
\hline \multirow[t]{2}{*}{ Time $(\mathbf{h})$} & \multicolumn{4}{|c|}{$A_{450}$} \\
\hline & \multicolumn{2}{|c|}{ Periodate } & \multicolumn{2}{|c|}{ Control } \\
\hline 20 & \multicolumn{2}{|c|}{$0.529 \pm 0.076$} & \multicolumn{2}{|c|}{$1 \cdot 531 \pm 0.069$} \\
\hline 4 & \multicolumn{2}{|c|}{$1 \cdot 167 \pm 0 \cdot 034$} & \multicolumn{2}{|c|}{$1.556 \pm 0.054$} \\
\hline 3 & \multicolumn{2}{|c|}{$1 \cdot 283 \pm 0 \cdot 057$} & \multicolumn{2}{|c|}{$1 \cdot 457 \pm 0.169$} \\
\hline 2 & \multicolumn{2}{|c|}{$1 \cdot 421 \pm 0.039$} & \multicolumn{2}{|c|}{$1 \cdot 581 \pm 0 \cdot 071$} \\
\hline 1 & \multicolumn{2}{|c|}{$1 \cdot 454 \pm 0 \cdot 106$} & \multicolumn{2}{|c|}{$1 \cdot 485 \pm 0 \cdot 153$} \\
\hline
\end{tabular}

tion; all tested positive for recognition of the immunogen ( $\beta$-1,3-glucanase; ICN 198904). One of the mAbs produced (MF2) was selected for further testing on the basis of its high absorbance value $\left(A_{450}>1.500\right)$. In secondary specificity screening tests, MF2 reacted strongly in an ELISA against surface antigens from all of the Trichoderma isolates tested and with antigens from the closely related fungi Gliocladium viride, Hypocrea rufa, Hypocrea gelatinosa, Hypocrea lutea, Hypomyces chrysospermus, Sphaerostilbella aureonitens and Sphaerostilbella novaezelandiae (Table 1). MF2 reacted weakly with surface antigens from Hypocrea pallida and did not react with surface antigens from the related fungi Clonostachys rosea, Clonostachys solani, Gliocladium roseum, Gliocladium catenulatum (Gliocladium roseum var. viride), Nectria ochroleuca and Sphaerostilbella lutea. MF2 did not react with surface antigens from a broad range of soil- and compost-borne fungi unrelated to Trichoderma spp. In all cases the absorbance value at $450 \mathrm{~nm}$ in ELISAs was $<0 \cdot 100$. The MF2 cell line was subcloned twice.

Isotyping of MF2 showed that it belonged to immunoglobulin class $\mathrm{M}(\operatorname{Ig} \mathrm{M})$.

\section{Characterization of the antigen and the effect of protease and periodate}

Reductions in MF2 binding following digestion of the immobilized immunogen with protease showed that the antibody binds to a protein epitope (Table 2). More specifically, the sensitivity of the epitope to trypsin indicated that MF2 binds to an antigenic determinant that contains residues of the amino acids serine and threonine. The sensitivity of the immunogen to periodate (Table 2) showed that the epitope forms part of a larger glycoprotein molecule.

\section{Growth of mycelium and antigen production on glucose and laminarin}

MF2 exhibited strong recognition of the immunogen in ELISAs. There was a typical sigmoidal relationship between the $\log _{10}$ protein concentration and the absorbance at $450 \mathrm{~nm}$, with a limit of detection of appoximately $0.5 \mathrm{ng}$ protein $(\mathrm{ml} \text { buffer })^{-1}$ (Fig. 1a). Growth of Trichoderma koningii TLS mycelium in liquid medium containing glucose rose steadily for 6 days after inoculation, until a plateau in growth was reached between days 6 and 9. Thereafter, growth declined up to day 12 (Fig. 1b). Growth in the presence of laminarin was similar, albeit less over the sampling period; however, following a peak in biomass at day 6 , there was a steady decline in mycelium production up to day 12. Temporal production of the MF2 antigen by Trichoderma koningii TLS grown in liquid medium containing either glucose or laminarin was similar (Fig. 1c). In both cases, antigen production increased up to 3 days post-inoculation, after which time production declined up to day 6 on laminarin and up to day 9 on glucose. Thereafter, the antigen concentrations present in cultures grown in both media increased up to 12 days post-inoculation.

\section{Enzyme activity assays}

The chromatographically purified $\beta$-1,3-glucanase preparation from ICN (immunogen) contained $3 \cdot 1 \pm 0 \cdot 0$ and 


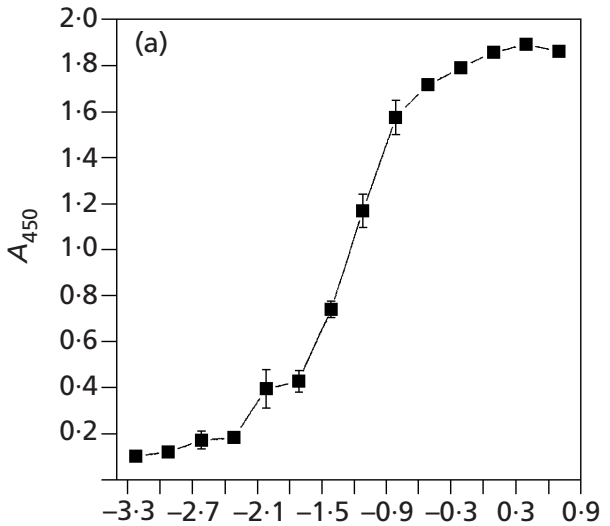

$\log _{10}$ protein concn [ $\mu \mathrm{g}$ protein (ml buffer) ${ }^{-1}$ ]
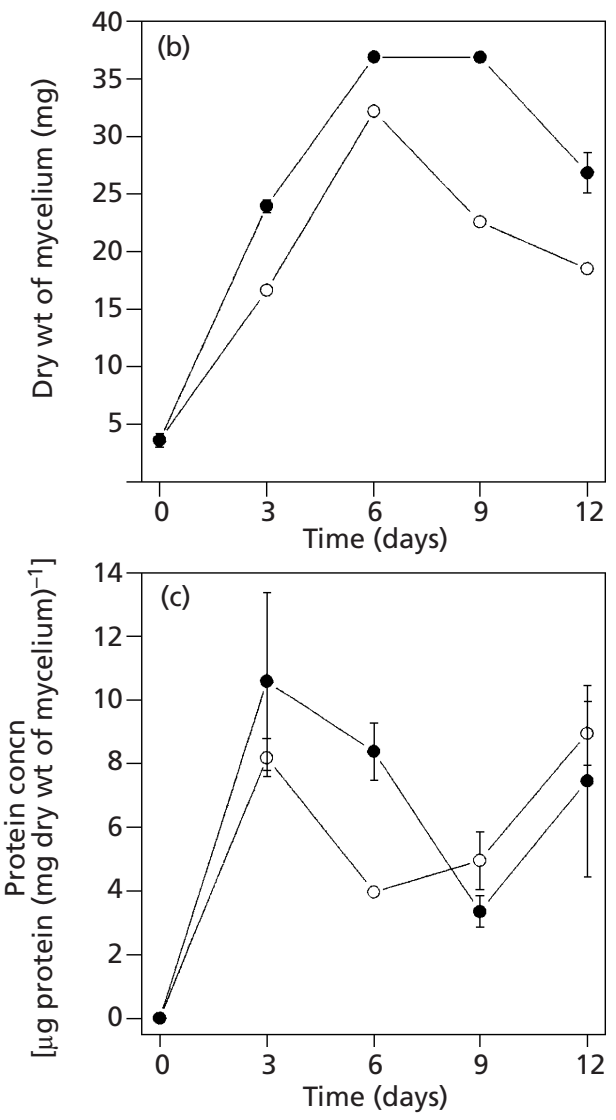

Fig. 1. (a) Standard calibration curve for the immunogen. (b) Growth of Trichoderma koningii isolate TLS in liquid cultures containing glucose (O) and laminarin ( $\bigcirc$ ). (c) Antigen production by Trichoderma koningii isolate TLS in liquid cultures containing glucose $(\bullet)$ and laminarin $(\bigcirc)$. All points are the mean of three replicate samples \pm SE. The antigen contents of the filtrates were determined by converting the absorbance values obtained from ELISAs (with MF2) to equivalents of protein concentration using the standard calibration curve.

$3 \cdot 2 \pm 0 \cdot 1$ units of $\beta-1,3$-glucanase and amylase activity, respectively. Protein samples concentrated from 5-dayold laminarin culture filtrates of Trichoderma koningii TLS contained $15 \cdot 1 \pm 0 \cdot 2$ and $17 \cdot 6 \pm 0 \cdot 3$ units of $\beta-1,3-$ glucanase and amylase activity, respectively. Protein samples concentrated from glucose cultures contained

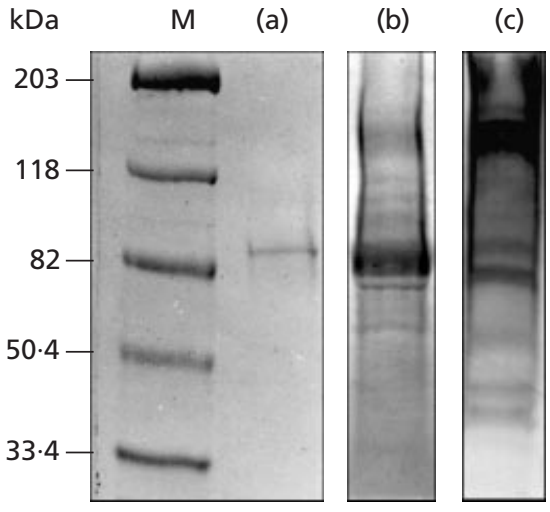

Fig. 2. Analysis of chromatographically purified $\beta$-1,3-glucanase preparation by PAGE and Western-blotting analyses. $M$ represents the molecular mass marker. (a) Denaturing SDS-PAGE followed by staining for protein with Coomassie blue. (b) Denaturing SDS-PAGE followed by staining with the carbohydratespecific PAS reaction, for the detection of glycoproteins. (c) Western immunoblot (with MF2) following separation of the immunogen by SDS-PAGE under reducing conditions. All wells were loaded with $1.25 \mu \mathrm{g}$ protein.

$\begin{array}{llll}\text { Immunogen } & 1 & \text { A V D D F IN T Q-P I A L N NLL } & 17 \\ H . \text { grisea } & 32 & \text { A V DT F I T TE K P I AW NKLL } & 49 \\ N . \text { crassa } & 36 & \text { S VDS YIQ TE T P I AQ K NLL } & 53\end{array}$

Fig. 3. Comparison of the $\mathrm{N}$-terminal-amino-acid sequence of the purified $\beta$-1,3-glucanase preparation (immunogen) with amino acid sequences held in the NCBI databases. The sequences from Humicola grisea and Neurospora crassa shared $72 \%$ and $55 \%$ identity, respectively, with the immunogen. Identical amino acids are underlined.

$3 \cdot 6 \pm 0 \cdot 1$ and $6 \cdot 6 \pm 0 \cdot 3$ units of $\beta-1,3$-glucanase and amylase activity, respectively.

\section{PAGE and Western blotting}

Denaturing PAGE of the purified immunogen followed by staining with Coomassie blue revealed a single protein with a molecular mass of approximately $90 \mathrm{kDa}$ (Fig. 2a). Staining of replica gels with the PAS reaction, for the detection of carbohydrate residues in glycoproteins, revealed an intensely stained, diffuse band in the range $80-90 \mathrm{kDa}$, a diffuse band at approximately $150 \mathrm{kDa}$ and additional weaker bands in the ranges 90-120 and $30-50 \mathrm{kDa}$ (Fig. 2b). All bands were red, indicating the presence of highly glycosylated proteins. No other bands were detected using this technique over a range of protein concentrations, and silver staining did not improve the sensitivity of detection (results not shown). Western-blotting analysis of the immunogen under denaturing conditions showed that MF2 bound to two bands with molecular masses in the range 80$90 \mathrm{kDa}$, a diffuse band at approximately $150 \mathrm{kDa}$ and two weaker bands in the range $30-50 \mathrm{kDa}$ (Fig. 2c). 


\section{$\mathrm{N}$-terminal sequence analysis}

Comparison of the $\mathrm{N}$-terminal amino acid sequence of the immunogen with amino acid sequences held in the NCBI databases revealed close identity with glucoamylases (1,4- $\alpha$-D-glucan glucohydrolase, EC 3.2.1.3) from Humicola grisea and Neurospora crassa (Fig. 3). Sequence alignment of the immunogen with the glucoamylases of Humicola grisea and Neurospora crassa showed $72 \%$ and $55 \%$ amino acid identity, respectively.

\section{IF and immunogold electron microscopy}

In IF studies, there was strong recognition by MF2 of the cell walls of the mycelium and phialides of Trichoderma sp. CST1 (Fig. 4a, b) and Trichoderma virens JI3-A8 (Fig. 4c, d). There was no binding by MF2 to the mature phialoconidia of either fungus, but binding to the cell walls of developing conidia was apparent (Fig. 4d). Strong binding by MF2 to the intercalary and terminal chlamydospores of Trichoderma sp. CST1 was also observed (Fig. 4e, f). There was intense staining of the cell walls of germ tubes of Trichoderma sp. CST1 by MF2, but no staining of the conidium was observed (Fig. $4 \mathrm{~g}, \mathrm{~h}$ ). Strong binding of MF2 to the germ tubes and conidia of Trichoderma koningii isolate TLS was observed (Fig. 4i, j).

In dual culture studies with Trichoderma sp. S-B2 and Rhizoctonia solani isolate $\mathrm{AB} 1$, there was intense staining of the Trichoderma sp. S-B2 hyphae that coiled around the Rhizoctonia solani mycelium (Fig. 5a, b). The Rhizoctonia solani mycelium was not stained by MF2 (Fig. 5b).

In immunogold electron microscopy studies with MF2, intense staining of the cell walls and septa of hyphae of the mycelium of Trichoderma koningii isolate TLS was observed when an immunogold conjugate was used as a secondary reporter (Fig. 6a). Strong staining was also exhibited by the cell walls of Trichoderma koningii TLS phialoconidia (Fig. 6c). There was no staining of control samples by the immunogold conjugate (Fig. 6b, d).

\section{Setting of thresholds for the baiting-ELISA method}

A threshold absorbance value was determined for each of the composts tested, above which individual baits in ELISAs were assigned as positive for the presence of Trichoderma spp. Threshold values were determined by plotting the frequencies of absorbance values obtained from each compost against stepwise increments $(0 \cdot 100)$ in absorbance (Thornton et al., 1999). The histograms generated were examined for discontinuity in the distribution of absorbance, with a tight clustering of samples expected at low absorbance, indicative of background values for samples with no Trichoderma spp., and higher values for absorbance indicative of the presence of a variable amount of Trichoderma spp. All baits that were colonized with fungi other than Trichoderma spp., or those that were uncolonized, consistently gave absorbance values $<0 \cdot 100$. These were identified as background values. Quinoa seed baits that were colonized with fungi positively identified as Trichoderma spp. gave absorbance values in ELISAs that were consistently $>0 \cdot 100$. Consequently, the threshold value of 0.100 was set, above which baits were considered to be positive for the presence of Trichoderma spp. Formal statistical analysis of thresholds, by fitting probability distributions and setting cut-off values, was precluded because of the absence of independent data for populations of test composts with and without Trichoderma spp. present.

\section{Immunoassay of the baits from naturally infested composts}

For each of the nine composts, the number of baits positive for Trichoderma spp., fixed by a threshold absorbance value of $0 \cdot 100$, was determined in a total of 18 baits (distributed between two replicate dishes, A and $\mathrm{B}$, for each compost). In all cases, results from the ELISAs were in close agreement with those from the plate-culture assays (Table 3). Differences in absorbance values were most likely due to variations in the fungal biomass present on individual baits.

\section{Plate culture of baits}

Following assay by ELISA, baits were removed from the microtitre wells and were transferred to TME medium. The number of baits colonized by fungal contaminant(s), either in the presence or absence of Trichoderma spp., after 3 days exposure to the compost surfaces varied (Table 3). The predominant contaminating fungi in all of the composts examined were identified as species belonging to the genera Botrytis, Fusarium, Mucor, Penicillium, Rhizopus, Verticillium and Zygorrhynchus. The number of quinoa seed baits colonized by Trichoderma isolates was in close agreement with the results from the ELISA (Table 3). The greater number of positive identifications by the ELISA compared to the plate-culture assay was due to exclusion of Trichoderma isolates by faster-growing fungal contaminants. It was for this reason that not all Trichoderma isolates could be recovered from baits that tested positive in ELISA (Table 3). Surface antigens were prepared from all of the Trichoderma isolates and from representative isolates of contaminating fungi recovered from the baits. These were tested by ELISA to confirm the recognition of recovered Trichoderma isolates by MF2 and to corroborate the lack of recognition of contaminating fungi by MF2. All of the recovered Trichoderma isolates tested positive in an ELISA with MF2, with no detection of contaminating fungi by the $\mathrm{mAb}$ (Table 1).

\section{Confirmation of identity of isolates as Trichoderma spp. by ITS region sequencing}

Representative isolates of fungi, detected and recovered from naturally infested composts using MF2, were 

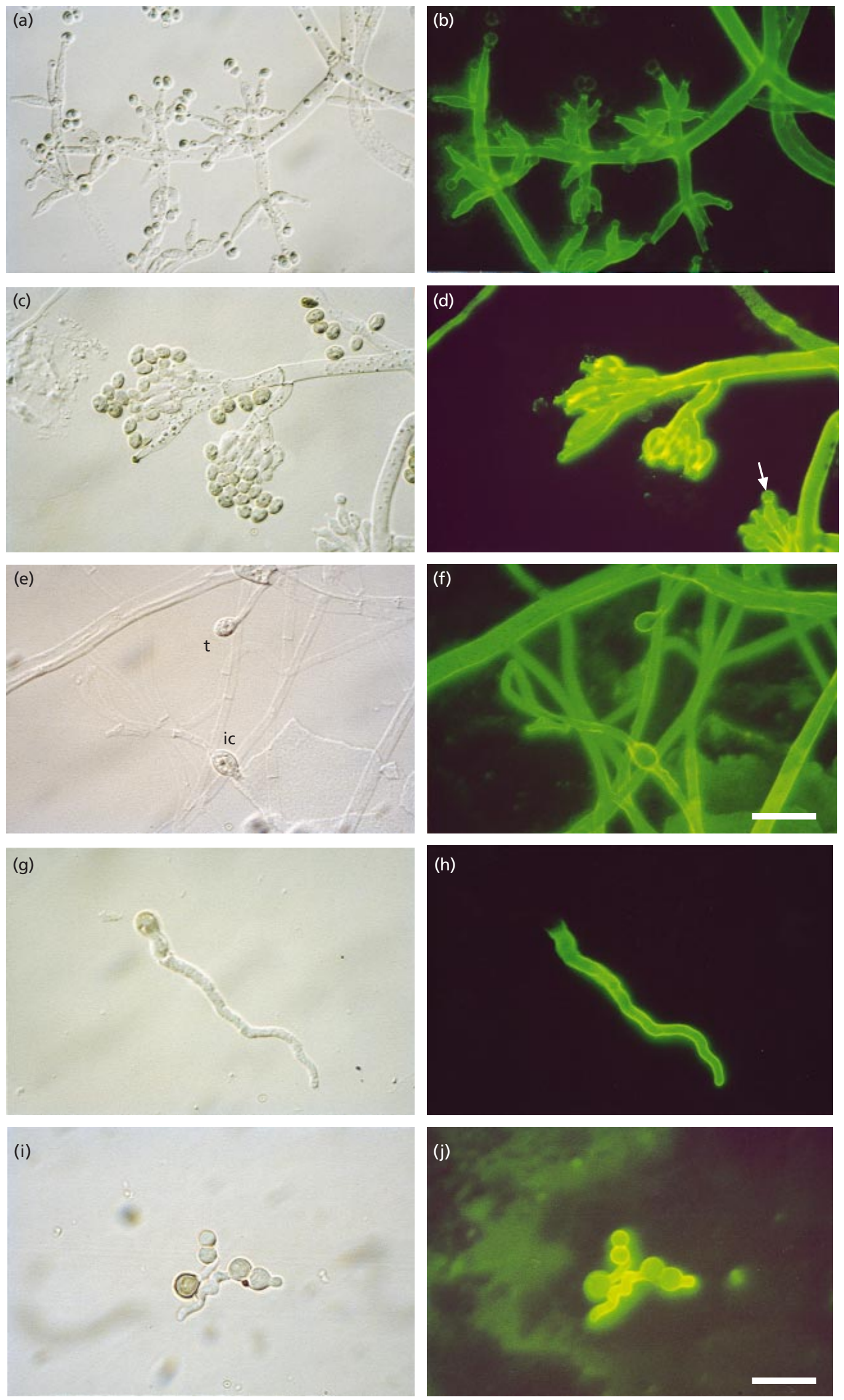

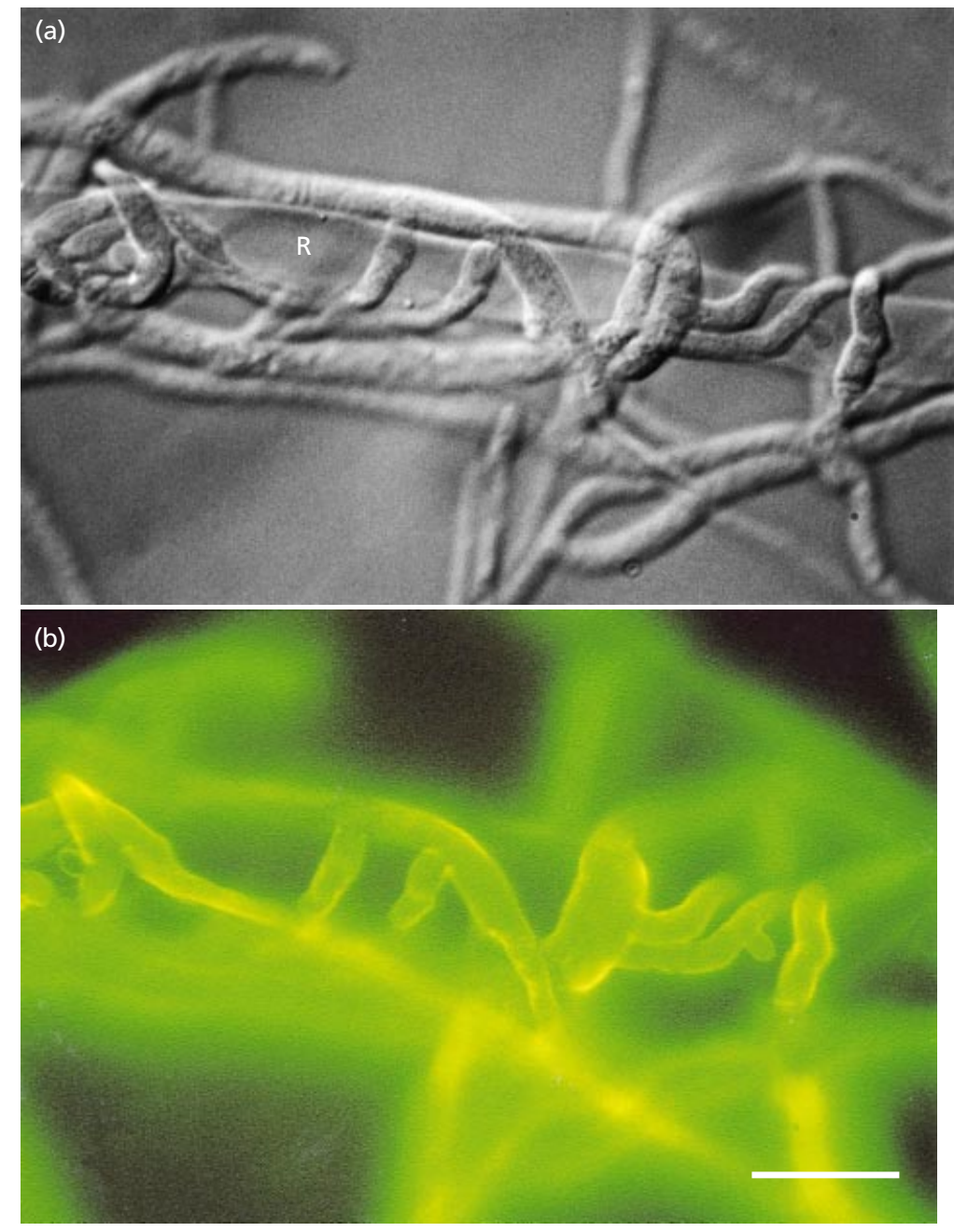

Fig. 5. Photomicrographs of Trichoderma isolate S-B2 and Rhizoctonia solani isolate $A B 1$ grown on glass slides in dual culture, and immunostained with MF2 and antimouse polyvalent immunoglobulin FITC. (a) Mycelium examined under bright-field microscopy, showing coiling of the hyperparasite Trichoderma harzianum around hypha of its host, Rhizoctonia solani (R). (b) Same slide as in (a), but examined under epifluorescence. The intense staining of the cell walls of the Trichoderma mycelium and the unstained hypha of Rhizoctonia solani can be seen. Bar, $10 \mu \mathrm{M}$. confirmed as Trichoderma spp. by comparison of their nucleic acid sequences (ITS1-5.8S-ITS2 rRNA-encoding regions) with those contained within databases held at the NCBI website (Table 4). The phylogeny of the Trichoderma isolates tested is shown in Fig. 7. The Trichoderma isolates were distributed amongst five clades that equated to five species, namely Trichoderma asperellum, Trichoderma hamatum, Trichoderma harzianum, Trichoderma virens and Trichoderma viride. Isolates CST1 and TLS were Trichoderma spp. used in this study, but whose affiliation with the Trichoderma fungi had not previously been determined. Isolate TLS (accession no. AF483581) fell within a clade consisting of a single isolate of Trichoderma koningii and was therefore referred to as Trichoderma koningii isolate TLS. Isolate CST1 (accession no. AF483580) fell within a clade consisting of Hypocrea vinosa, Trichoderma asperellum, Trichoderma harzianum and Trichoderma viride and Trichoderma isolate S-B2, recovered in this study from naturally infested Shamrock compost. Consequently, CST1 and S-B2 are referred to in the text as Trichoderma isolates CST1 and S-B2 or in tables as Trichoderma sp. Ambiguity also exists with respect to the identification of HBC-A2, isolated from Homebase compost, and it is therefore referred to in Tables 1 and 4 as Trichoderma sp. HBC-A2.

Fig. 4. Photomicrographs of Trichoderma sp. CST1 cells and Trichoderma virens cells immunostained with MF2 and antimouse polyvalent immunoglobulin FITC. (a) Hyphae, phialides and phialoconidia of Trichoderma CST1 examined under bright-field microscopy; (b) same slide as in (a), but examined under epifluorescence. (c) Hyphae, phialides and phialoconidia of Trichoderma virens isolate JI3-A8 examined under bright-field microscopy; (d) same slide as in (c), but examined under epifluorescence. The mature conidia were not stained, but the cell wall of an immature conidium exuded from the tip of a phialide was (shown by an arrow). (e) Intercalary (ic) and terminal (t) chlamydospores of Trichoderma sp. CST1 examined under bright-field microscopy; (f) same slide as in (e), but examined under epifluoresence. (g) Germinated conidium of Trichoderma sp. CST1 examined under bright-field microscopy; (h) same slide as in (g), but examined under epifluoresence. The cell wall of the germ tube was intensely stained, but no staining of the conidium was seen. (i) Germinated and ungerminated conidia of Trichoderma koningii isolate TLS examined under bright-field microcopy; (j) same slide as in (i), but examined under epifluoresence. The cell walls of the germ tubes and conidia were intensely stained. Bar, $10 \mu \mathrm{M}$. 

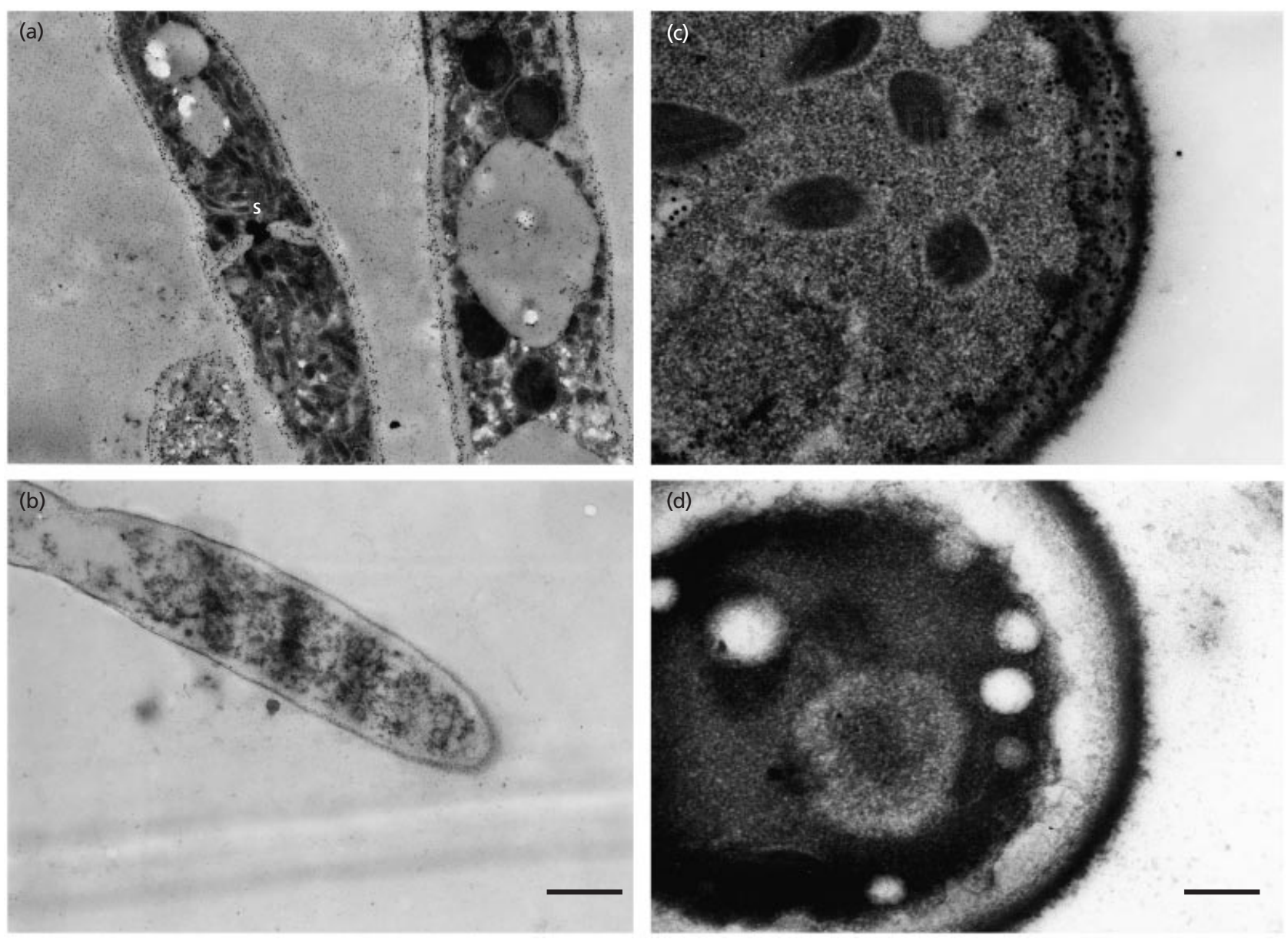

Fig. 6. Immunogold labelling of sections of cells of Trichoderma koningii isolate TLS. (a) Section of mycelium incubated with MF2 and anti-mouse immunoglobulin $20 \mathrm{~nm}$ gold particles, showing intense staining of the cell walls and septum (s) by the secondary reporter. (b) Control section of mycelium incubated with tissue culture medium and the immunogold conjugate. There was a lack of staining by the secondary reporter. Bar, 1.0 $\mu \mathrm{M}$. (c) Section of conidium incubated with MF2 and the immunogold conjugate, showing intense staining of the cell wall by the secondary reporter. (d) Control section of conidium incubated with tissue culture medium and the immunogold conjugate. There was a lack of staining by the secondary reporter. Bar, $220 \mathrm{~nm}$.

\section{DISCUSSION}

The development and testing of immunoassays in previous investigations (Thornton et al., 1993, 1997, 1999; Thornton \& Gilligan, 1999) has shown that the most appropriate antigens for the detection of fungi in soils and composts are those that are extracellular and that are constitutively expressed or can be induced by specific substrates. Studies of extracellular antigen production in Trichoderma spp. have shown that the enzyme $\beta$-1,3-glucanase represents an ideal candidate for the production of mAbs specific to this genus, since the enzyme is extracellular and is produced constitutively or semi-constitutively (Bull \& Chesters, 1966; Elad et al., 1982; Reese \& Mandels, 1959).

Using a chromatographically purified Trichoderma $\beta$ 1,3-glucanase preparation, a hybridoma cell line was raised which secreted an $\operatorname{IgM}$ class $\mathrm{mAb}, \mathrm{MF} 2$, that recognized a protein epitope specific to the genus Trichoderma and to a group of closely related fungi. The members of this group included species identified as part of a monophyletic clade by Rehner \& Samuels (1994), in a study using parsimony analysis of partial sequences from nuclear large subunit rDNA (28S rDNA). This clade contained elements of the genus Hypocrea (Hypocrea gelatinosa, Hypocrea lutea) plus Trichoderma spp., Hypocrea pallida, Hypomyces spp. and Sphaerostilbella spp. Gliocladium anamorphs in this clade included Gliocladium penicilliodes, the type species of Gliocladium and anamorph of Sphaerostilbella aureonitens, and Trichoderma virens (=Gliocladium virens), which was a member of the clade containing Hypocrea and Trichoderma. Rehner \& Samuels (1994) also identified a second clade grouped around Nectria ochroleuca, whose anamorph is Gliocladium roseum - neither Nectria ochroleuca nor 
Table 3. Results of ELISA and plate culture tests for naturally infested composts

Each sample was baited with nine quinoa seeds. Contaminating fungi were identified as species belonging to the genera Botrytis, Fusarium, Mucor, Penicillium, Rhizopus, Verticillium and Zygorrhynchus.

\begin{tabular}{|c|c|c|c|}
\hline \multirow[t]{2}{*}{ Compost } & \multicolumn{3}{|c|}{ No. of baits: } \\
\hline & $\begin{array}{l}\text { With fungal } \\
\text { contaminants }\end{array}$ & $\begin{array}{c}\text { From which } \\
\text { Trichoderma spp. } \\
\text { were recovered }\end{array}$ & $\begin{array}{c}\text { Positive for } \\
\text { Trichoderma spp. } \\
\text { in baiting-ELISA }\end{array}$ \\
\hline \multicolumn{4}{|l|}{ Bulrush } \\
\hline Sample A & 8 & 1 & 1 \\
\hline Sample B & 8 & 0 & $1^{*}$ \\
\hline \multicolumn{4}{|l|}{ Godwin } \\
\hline Sample A & 8 & 0 & 0 \\
\hline Sample B & 7 & 2 & 2 \\
\hline \multicolumn{4}{|l|}{ Homebase } \\
\hline Sample A & 4 & 1 & 1 \\
\hline Sample B & 6 & 1 & 1 \\
\hline \multicolumn{4}{|c|}{ John Innes No. 1} \\
\hline Sample A & 4 & 0 & 0 \\
\hline Sample B & 5 & 0 & 0 \\
\hline \multicolumn{4}{|c|}{ John Innes No. 2} \\
\hline Sample A & 8 & 0 & 0 \\
\hline Sample B & 5 & 0 & 0 \\
\hline \multicolumn{4}{|c|}{ John Innes No. 3} \\
\hline Sample A & 6 & 1 & 1 \\
\hline Sample B & 2 & 1 & 1 \\
\hline \multicolumn{4}{|l|}{ Levington } \\
\hline Sample A & 5 & 3 & $5^{*}$ \\
\hline Sample B & 8 & 1 & $2 *$ \\
\hline \multicolumn{4}{|l|}{ Shamrock } \\
\hline Sample A & 6 & 3 & $6^{*}$ \\
\hline Sample B & 5 & 4 & 4 \\
\hline \multicolumn{4}{|c|}{ Westcountry } \\
\hline Sample A & 4 & 0 & 0 \\
\hline Sample B & 6 & 0 & 0 \\
\hline
\end{tabular}

* Not all isolates from these samples could be recovered for further testing, due to exclusion by fastergrowing contaminating fungi.

Gliocladium roseum was recognized by MF2. Gliocladium roseum is distinguishable from other fungi by the formation of two distinct types of conidiophores, one Gliocladium-like and producing chains of conidia, and the other Verticillium-like and producing conidia in colourless drops of liquid (Domsch et al., 1980). However, the Verticillium-like synanamorph is not unique to Gliocladium roseum. Sphaerostilbella lutea also produces a Verticillium-like state and while the Verticillium-like synanamorphs produced by Gliocladium roseum and Sphaerostilbella lutea are not strictly equivalent, their close taxonomic proximity may explain the lack of recognition of Sphaerostilbella lutea antigens by MF2. MF2 also did not recognize species of the genus Clonostachys, which was proposed as the appropriate genus for the Gliocladium roseum anamorph by Domsch et al. (1980).

ELISA studies showed that production of the MF2 antigen, by actively growing mycelium of Trichoderma koningii, was constitutive and occurred in the absence of laminarin, a substrate shown to induce the production of $\beta$-1,3-glucanases in Trichoderma spp. (De La Cruz et al., 1993, 1995; Noronha \& Ulhoa, 1996; VasquezGarciduenas et al., 1998). Furthermore, extracellular antigen production by Trichoderma koningii was as pronounced in the presence of glucose as in the presence of laminarin. This suggested that MF2 had been raised against an antigen other than $\beta$-1,3-glucanase or against additional antigens that shared a common epitope with 
Table 4. Absorbance values obtained in ELISA from baits of naturally infested composts and species designation of recovered isolates as determined by ITS sequence analysis

\begin{tabular}{|c|c|c|c|c|}
\hline Compost & Isolate no. & $\begin{array}{l}\text { Absorbance value in } \\
\text { baiting-ELISA* }\end{array}$ & Species & Accession no. \\
\hline Bulrush & BUL-A7 & $0 \cdot 130$ & Trichoderma viride & AF483589 \\
\hline \multirow[t]{2}{*}{ Godwin } & GOD-B4 & $0 \cdot 253$ & Trichoderma hamatum & AF483582 \\
\hline & GOD-B7 & $0 \cdot 153$ & Trichoderma hamatum & AF483594 \\
\hline \multirow[t]{2}{*}{ Homebase } & HBC-A2† & $0 \cdot 488$ & Trichoderma sp. & AF483584 \\
\hline & HBC-B4 & $0 \cdot 439$ & Trichoderma viride & AF483583 \\
\hline \multirow[t]{2}{*}{ John Innes No. 3} & JI3-A8 & $0 \cdot 937$ & Trichoderma virens & AF483585 \\
\hline & JI3-B7 & $0 \cdot 235$ & Trichoderma virens & AF483586 \\
\hline \multirow[t]{4}{*}{ Levington } & LEV-A2 & 0.753 & Trichoderma sp. & \\
\hline & LEV-A8 & $0 \cdot 606$ & Trichoderma harzianum & AF483587 \\
\hline & LEV-A9 & $0 \cdot 948$ & Trichoderma sp. & \\
\hline & LEV-B7 & $1 \cdot 062$ & Trichoderma harzianum & AF483588 \\
\hline \multirow[t]{7}{*}{ Shamrock } & S-A1 & $0 \cdot 168$ & Trichoderma sp. & \\
\hline & S-A3 & $0 \cdot 146$ & Trichoderma sp. & \\
\hline & S-A8 & $0 \cdot 417$ & Trichoderma viride & AF483590 \\
\hline & $\mathrm{S}-\mathrm{B} 2 \dagger$ & $0 \cdot 363$ & Trichoderma sp. & AF483591 \\
\hline & S-B3 & $0 \cdot 249$ & Trichoderma viride & AF483592 \\
\hline & S-B5 & $0 \cdot 144$ & Trichoderma sp. & \\
\hline & S-B9 & $0 \cdot 548$ & Trichoderma viride & AF483593 \\
\hline
\end{tabular}

* Threshold absorbance value for detection of Trichoderma spp. in baiting-ELISA was set at $A_{450}=0 \cdot 100$.

† Species affiliation could not be assigned due to ambiguity in phylogeny when using ITS sequences.

the enzyme. Furthermore, these antigen(s) must have been present as contaminants in the enzyme preparation.

Analysis of the chromatographically purified enzyme preparation by gel electrophoresis followed by staining with Coomassie blue revealed a single $90 \mathrm{kDa}$ protein. However, staining of replica gels for carbohydrate, using the PAS reaction, revealed highly glycosylated proteins with masses in the range $80-200 \mathrm{kDa}$. Nterminal sequence analysis of the preparation revealed a protein sequence (Ala-Val-Asp-Asp-Phe-Ile-AsnThr-Gln-Pro-Ile-Ala-Leu-Asn-Asn-Leu-Leu-Asn) with strong identity, in database searches, to glucoamylases from Humicola grisea and Neurospora crassa and to a previously reported N-terminal sequence for Trichoderma reesei glucoamylase (Val-Asp-Asp-Phe-Ile-SerThr-Glu-Thr/Asn-Pro-Ile-Ala-Leu-Asn) (Fagerstrom, 1994). An assay of the purified preparation for enzyme activities revealed both $\beta$-1,3-glucanase and amylase activities. Similarly, both activities were also found in acetone precipitates from 5-day-old cultures of Trichoderma koningii grown in the presence of glucose or laminarin. The constitutive nature of secretion of both enzymes in the absence of their natural substrates would account for the strong reactivity of MF2 with culture filtrates and surface washings from slope cultures of Trichoderma spp.

Western-blotting analysis of the immunogen preparation showed that MF2 bound to a ladder of proteins whose molecular masses corresponded to those of proteins visualized by Coomassie blue and PAS staining.
The molecular masses of these bands were in keeping with those described elsewhere for Trichoderma glucoamylases and $\beta$-1,3-glucanases. For example, Fagerstrom \& Kalkkinen (1995) reported a $66 \mathrm{kDa}$ glucoamylase in Trichoderma reesei, while Okada (1977) described a $75 \mathrm{kDa}$ glucoamylase in Trichoderma viride. Studies of Trichoderma $\beta$-1,3-glucanases have revealed single, inducible enzymes with molecular masses of $78 \mathrm{kDa}(\mathrm{De}$ La Cruz et al., 1995) and $36 \mathrm{kDa}$ (Noronha \& Ulhoa, 1996), at least seven inducible enzymes with masses in the range 35-80 kDa (Vazquez-Garciduenas et al., 1998) and a complex system of constitutive and inducible enzymes with molecular masses in the range $30-200 \mathrm{kDa}$ (Ramot et al., 2000).

From the results of this study, and those described elsewhere, we conclude that MF2 binds either to a protein epitope specific to glucoamylases produced by Trichoderma spp. and closely related fungi or to a protein epitope that is shared by glucoamylases and by $\beta$-1,3-glucanases, but which is specific to the enzymes secreted by Trichoderma spp. and closely related fungi.

Localization of the MF2 antigen(s) by immunogold electron microscopy showed that it was expressed in hyphal cell walls and septa and in the cell walls of phialoconidia; IF studies further illustrated its extracellular nature. This pattern of staining is consistent not only with the cellular localization of constitutive $\beta-1,3-$ glucanases in Trichoderma harzianum (Gohl et al., 1998), but also with the distribution of glucoamylase secretion in Aspergillus niger (Gordon et al., 2000). 


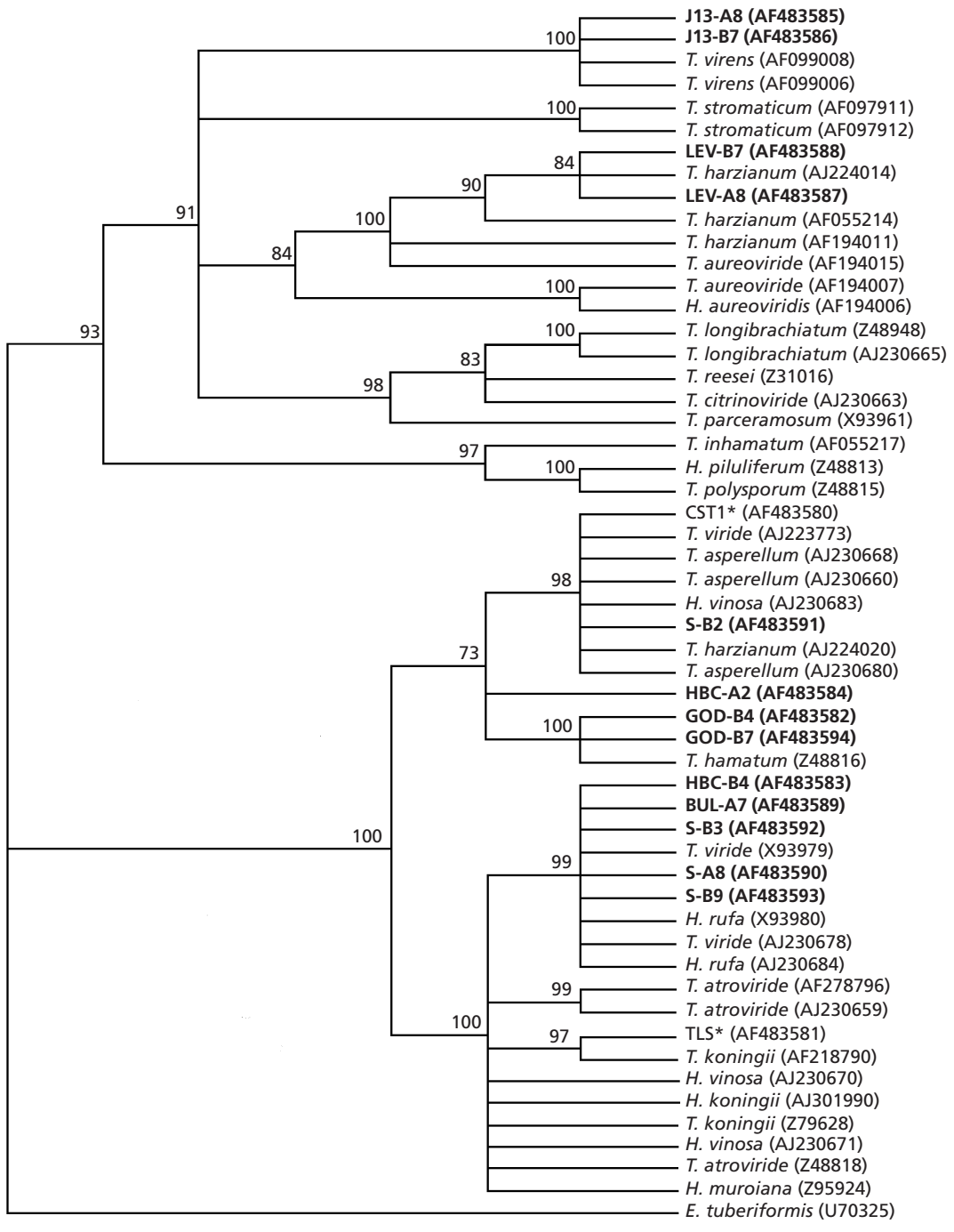

Fig. 7. Fifty percent majority-rule consensus tree based on ITS1-5.8S-ITS2 sequences of Trichoderma isolates detected and recovered from naturally infested composts using MF2 (bold type) compared with sequences of fungi contained in GenBank. Relationships were determined using the neighbourjoining method in PAUP* (version 4.0). Bootstrap values, shown as a percentage of 1000 replications, are given at branches; only those associations that were present in $>50 \%$ of the replicate trees are shown at the nodes. Echinodothis tuberiformis was used as the outgroup. Accession numbers of GenBank isolates are shown in parenthesis after species names. Isolates followed by an asterisk are Trichoderma spp. that were used in this study, but whose species affiliation to the genus has not previously been determined.
Production of a mAb to a constitutive, extracellular, antigen enabled the development of an immunoassay for the detection of Trichoderma spp. in complex environments such as composts. By combining a baiting procedure with ELISA, we were able to detect and recover isolates of Trichoderma spp. present in naturally infested commercial compost preparations. The specificity of the $\mathrm{mAb}$ was illustrated in vivo by its ability to differentiate Trichoderma spp. from contaminant fungi of unrelated genera, whereas its ability to detect isolates from a range of closely related species was shown by the recovery and characterization of the isolates by analysis of the nuclear ITS regions of the rRNA-encoding gene unit. The widespread occurrence of different Trichoderma spp. in the compost preparations was most likely due to their composition. All of the samples tested, with the exception of a single greenwaste compost where no Trichoderma spp. were detected, were composed of sphagnum or sedge peats. Natural populations of Trichoderma and Gliocladium spp. occur in high numbers or predominate in peat deposits (Dickinson \& Dooley, 1969; Domsch et al., 1980).
The ability to recover fungal isolates using plateenrichment techniques after immunodetection allowed us to examine whether any of the strains exhibited potential biological control properties. [These control properties have been defined as the production of antibiotics and lytic enzymes, and physical interactions with host hyphae (Chet et al., 1981; Elad et al., 1983; Sivan \& Chet, 1989; Benhamou \& Chet, 1993)]. A Trichoderma isolate (S-B2), detected and recovered in this study using the combined baiting-ELISA method, emitted a strong coconut odour, characteristic of Trichoderma strains that produce the volatile antibiotic alkyl pyrone (Claydon et al., 1987; Ghisalberti \& Sivasithamparam, 1991; Maplestone et al., 1991). The production of this antibiotic by Trichoderma spp. has been shown to significantly affect the saprotrophic growth of Rhizoctonia solani in compost-based systems (Thornton \& Gilligan, 1999). Isolate S-B2 also exhibited directed growth toward - and coiling around - hyphae of the plant pathogen Rhizoctonia solani in vitro, which was visualized by IF microscopy using MF2. MF2 is currently being used to monitor the growth and survival of Trichoderma S-B2 and Trichoderma virens JI3-A8 
during their antagonistic interactions with Rhizoctonia solani and Pythium ultimum in plant rhizosphere and bulk soil studies, under controlled laboratory conditions.

We believe that the identification of MF2 represents a significant advance in the specific immunological detection and monitoring of Trichoderma spp. in complex environments such as composts and soils. This mAb could be used in conjunction with nucleic-acid-based diagnostic techniques (Abbasi et al., 1999; Hermosa et al., 2001) to aid in the rapid detection, specific monitoring, recovery and identification of Trichoderma spp.

\section{ACKNOWLEDGEMENTS}

This work was funded in part by a University of Exeter Research Fellowship held by C. R. Thornton, and in part by a grant to C.R. Thornton and N.J. Talbot from the Biotechnology and Biological Sciences Research Council (grant no. BRE13618), to whom we are grateful. The authors would like to thank Dr J. Stevens (Exeter University) for advice on phylogenetic analysis.

\section{REFERENCES}

Abbasi, P. A., Miller, S. A., Meulia, T., Hoitink, H. A. J. \& Kim, J.-H. (1999). Precise detection and tracing of Trichoderma hamatum 382 in compost-amended potting mixes by using molecular markers. Appl Environ Microbiol 65, 5421-5426.

Ahmad, J. S. \& Baker, R. (1988). Rhizosphere competence of benomyl tolerant mutants of Trichoderma spp. Can J Microbiol 34, 694-696.

Altschul, S. F., Madden, T. L., Schaffer, A. A., Zhang, Z., Miller, W. \& Lipman, D. J. (1997). Gapped BLAST and PSI-BLAST: a new generation of protein database programs. Nucleic Acids Res 25, 3389-3402.

Bae, Y. S. \& Knudsen, G. R. (2000). Co-transformation of Trichoderma harzianum with beta-glucuronidase and green fluorescent protein genes provides a useful tool for monitoring fungal growth and activity in natural soils. Appl Environ Microbiol 66, 810-815.

Benhamou, N. \& Chet, I. (1993). Hyphal interactions between Trichoderma harzianum and Rhizoctonia solani: ultrastructure and gold cytochemistry of the mycoparasitic process. Phytopathology 83, 1062-1071.

Bull, A. T. \& Chesters, C. G. C. (1966). The biochemistry of laminarin and the nature of laminarinase. Adv Enzymol Relat Areas Mol Biol 28, 325-364.

Carlsson, S. R. (1993). Isolation and characterisation of glycoproteins. In Glycobiology, a Practical Approach, pp. 1-26. Edited by M. Fakuda \& A. Kobata. Oxford, UK: IRL Press.

Chet, I., Harman, G. E. \& Baker, R. (1981). Trichoderma hamatum: its hyphal interactions with Rhizoctonia solani and Pythium spp. Microb Ecol 7, 29-38.

Claydon, N., Allan, M., Hanson, J. R. \& Avent, A. G. (1987). Antifungal alkyl pyrones of Trichoderma harzianum. Trans $\mathrm{Br}$ Mycol Soc 88, 503-513.

Cole, L., Dewey, F. M. \& Hawes, C. R. (1998). Immunocytochemical studies of the infection mechanisms of Botrytis fabae. I. The fungal extracellular matrix in penetration and post-penetration processes. New Phytol 139, 597-609.
Cullen, D. \& Kersten, P. (1992). Fungal enzymes for lignocellulose degradation. In Applied Molecular Genetics of Filamentous Fungi, pp. 100-131. Edited by J. R. Kinghorn \& G. Turner. Glasgow, UK: Blackie Academic \& Professional.

De La Cruz, J., Rey, M., Lora, J. M., Hidalgo-Gallego, A., Dominguez, F., Pintor-Toro, J. A., Llobell, A. \& Benitez, T. (1993). Carbon source control of $\beta$-glucanases, chitobiase and chitinase from Trichoderma harzianum. Arch Microbiol 159, 316-322.

De La Cruz, J., Pintor-Toro, J. A., Benitez, T., Llobell, A. \& Romero, L. C. (1995). A novel endo- $\beta$-1,3-glucanase, BGN13.1, involved in the mycoparasitism of Trichoderma harzianum. J Bacteriol 177, 6937-6945.

Dewey, F. M. (1992). Detection of plant invading fungi by monoclonal antibodies. In Techniques for the Rapid Detection of Plant Pathogens, pp. 42-47. Edited by J. M. Duncan \& L. Torrance. Oxford, UK: Blackwell Scientific Publications.

Dewey, F. M. \& Thornton, C. R. (1995). Fungal immunodiagnostics in plant agriculture. In New Diagnostics in Crop Sciences, pp. 151-171. Biotechnology in Agriculture no. 13. Edited by J. H. Skerrit \& R. Appels. Oxford, UK: CABI.

Dewey, F. M., Thornton, C. R. \& Gilligan, C. A. (1996). Use of monoclonal antibodies to detect, quantify and visualize fungi in soil. In Advances in Botanical Research Incorporating Advances in Plant Pathology 24, pp. 275-308. Edited by J. H. Andrews \& I. C. Tommerup. San Diego: Academic Press.

Dickinson, C. H. \& Dooley, M. (1969). Fungi associated with Irish peat bogs. Proc R Ir Acad Sect B Biol Geol Chem Sci 68, 109-137.

Domsch, K. H., Gams, W. \& Anderson, T. H. (1980). Compendium of Soil Fungi, vol. 1. London: Academic Press.

Elad, Y., Chet, I. \& Henis, Y. (1982). Degradation of plant pathogenic fungi by Trichoderma harzianum. Can J Microbiol 28, 719-725.

Elad, Y., Chet, I., Boyle, P. \& Henis, Y. (1983). Parasitism of Trichoderma sp. on Rhizoctonia solani and Sclerotium rolfsiiscanning electron microscopy and fluorescence microscopy. Phytopathology 73, 85-88.

Fagerstrom, R. (1994). Purification and specificity of recombinant Hormoconis resinae glucoamylase $\mathrm{P}$ and endogenous glucoamylase from Trichoderma reesei. Enzyme Microb Technol 16, 36-42.

Fagerstrom, R. \& Kalkkinen, N. (1995). Characterization, subsite mapping and partial amino acid sequence of glucoamylase from the filamentous fungus Trichoderma reesei. Biotechnol Appl Biochem 21, 223-231.

Ghisalberti, E. L. \& Sivasithamparam, K. (1991). Antifungal antibiotics produced by Trichoderma spp. Soil Biol Biochem 23, 1011-1020.

Gohl, M., Srinivas, R., Dammertz, W., Udupa, M. R. \& Panda, T. (1998). Localization of $\beta$-1,3-glucanases in Trichoderma harzianum. Bioprocess Eng 19, 237-241.

Gordon, C. L., Khalaj, V., Ram, A. F. J. \& 9 other authors (2000). Glucoamylase: green fluorescent protein fusions to monitor protein secretion in Aspergillus niger. Microbiology 146, 415-426.

Green, H. \& Jensen, D. F. (1995). A tool for monitoring Trichoderma harzianum. 2. The use of a GUS transformant for ecological studies in the rhizosphere. Phytopathology 85, 1436-1440.

Hermosa, M. R., Grondona, I., Diaz-Minguez, J. M., Iturriaga, E. A. \& Monte, E. (2001). Development of a strain-specific SCAR marker for the detection of Trichoderma atroviride 11, a biological control agent against soil-borne fungal plant pathogens. Curr Genet 38, 343-350. 
Jacobs, F., Byl, B., Burgeous, N. \& 7 other authors (1992). Trichoderma viride infection in a liver transplant recipient. Mycoses 35, 301-303.

Laemmli, U. K. (1970). Cleavage of structural proteins during assembly of the head of bacteriophage T4. Nature 227, 680-685.

Loeppke, C. B., Ronald, M. D., Sprouse, R. F., Carlson, J. V. \& Everett, E. D. (1983). Trichoderma viride peritonitis. South Med J 76, 798-799.

Maplestone, P. A., Whipps, J. M. \& Lynch, J. M. (1991). Effect of peat-bran inoculum of Trichoderma species on biological control of Rhizoctonia solani in lettuce. Plant Soil 136, 257-263.

Marck, C. (1989). DNA Strider 1.1. Service de Biochemie, Department de Biologie, Institute de Reserche Fondimentale, CEA, France.

Noronha, E. F. \& Ulhoa, C. J. (1996). Purification and characterization of an endo- $\beta$-1,3-glucanase from Trichoderma harzianum. Can J Microbiol 42, 1039-1044.

Okada, G. (1977). Glucoamylase from Trichoderma viride. J Jpn Soc Starch Sci 24, 120-127.

Otten, W., Gilligan, C. A. \& Thornton, C. R. (1997). Quantification of fungal antigens in soil with a monoclonal antibody-based ELISA: analysis and reduction of soil-specific bias. Phytopathology 87, 730-736.

Papavizas, G. C. (1982). Survival of Trichoderma harzianum in soil and in pea and bean rhizospheres. Phytopathology 72, 121-125.

Papavizas, G. C. (1985). Trichoderma and Gliocladium: biology, ecology, and potential for biocontrol. Annu Rev Phytopathol 23, 23-54.

Pe'er, S., Barak, Z., Yarden, O. \& Chet, I. (1991). Stability of Trichoderma harzianum amdS transformants in soil and rhizosphere. Soil Biol Biochem 23, 1043-1046.

Ramot, O., Cohen-Kupiec, R. \& Chet, I. (2000). Regulation of $\beta-1,3-$ glucanase by carbon starvation in the mycoparasite Trichoderma harzianum. Mycol Res 104, 415-420.

Reese, E. T. \& Mandels, M. (1959). $\beta-1,3-$ Glucanase in fungi. Can J Microbiol 5, 173-185.

Rehner, S. A. \& Samuels, G. J. (1994). Taxonomy and phylogeny of Gliocladium analysed from nuclear subunit ribosomal DNA sequences. Mycol Res 98, 625-634.

Richter, S., Cormican, M. G., Pfaller, M. A., Lee, C. K., Gingrich, R., Rinaldi, M. G. \& Sutton, D. A. (1999). Fatal disseminated Trichoderma longibrachiatum infection in an adult bone marrow transplant patient: species identification and review of the literature. J Clin Microbiol 37, 1154-1160.

Sandhu, D. K. \& Kalra, M. K. (1982). Production of cellulase, xylanase and pectinase by Trichoderma longibrachiatum on different substrates. Trans Br Mycol Soc 79, 409-413.

Seaby, D. A. (1987). Infection of mushroom compost by Trichoderma species. Mushroom J 179, 355-361.
Sivan, A. \& Chet, I. (1989). Degradation of fungal cell walls by lytic enzymes of Trichoderma harzianum. J Gen Microbiol 135, 675-682.

Sreenivasiprasad, S., Sharada, K., Brown, A. E. \& Mills, P. R. (1996). PCR-based detection of Colletotrichum acutatum on strawberry. Plant Pathol 45, 650-655.

Swofford, D. L. (2000). PAUP*, phylogenetic analysis using parsimony ("and other methods). Version 4.0b4a. Sunderland, MA: Sinauer.

Tanis, B. C., Van den Pijl, H., Van Ostrup, M. L., Kibbehaar, R. E. \& Chang, P. C. (1995). Fatal fungal peritonitis by Trichoderma longibrachiatum complicating peritoneal dialysis. Nephrol Dial Transplant 10, 114-116.

Thompson, J. D., Higgins, D. G. \& Gibson, T. J. (1994). ClustaL w : improving the sensitivity of progressive multiple sequence alignment through sequence weighting, position-specific gap penalties and weight matrix change. Nucleic Acids Res 22, 4673-4680.

Thornton, C. R. \& Gilligan, C. A. (1999). Quantification of the effect of the hyperparasite Trichoderma harzianum on the saprotrophic growth dynamics of Rhizoctonia solani in compost using a monoclonal antibody-based ELISA. Mycol Res 103, 443-448.

Thornton, C. R., Dewey, F. M. \& Gilligan, C. A. (1993). Development of monoclonal antibody-based immunological assays for the detection of live propagules of Rhizoctonia solani in the soil. Plant Pathol 42, 763-773.

Thornton, C. R., Dewey, F. M. \& Gilligan, C. A. (1997). Production and characterization of a monoclonal antibody raised against surface antigens from mycelium of Gaeumannomyces graminis var. tritici: evidence for an extracellular polyphenol oxidase. Phytopathology 87, 123-131.

Thornton, C. R., O'Neill, T. M., Hilton, G. \& Gilligan, C. A. (1999). Detection and recovery of Rhizoctonia solani in naturally infested glasshouse soils using a combined baiting, double monoclonal antibody ELISA. Plant Pathol 48, 627-634.

Thrane, C., Lubeck, M., Green, H., Degefu, Y., Allerup, S., Thrane, U. \& Jensen, D. F. (1995). A tool for monitoring Trichoderma harzianum. 1. Transformation with the GUS gene by protoplast technology. Phytopathology 85, 1428-1435.

Vasquez-Garciduenas, S., Leal, C. A. \& Herrera-Estrella, A. (1998). Analysis of the beta-1,3-glucanolytic system of the biocontrol agent Trichoderma harzianum. Appl Environ Microbiol 64, 1442-1446.

Whipps, J. M. (1997). Developments in the biological control of soil-borne plant pathogens. Adv Bot Res 26, 1-134.

White, T. J., Bruns, T., Lee, S. \& Taylor, J. (1990). Amplification and direct sequencing of fungal ribosomal RNA genes for phylogenetics. In PCR Protocols: a Guide to Methods and Applications, pp. 315-322. Edited by M. A. Innis, D. H. Gelfand, J. J. Sninsky \& T. J. White. San Diego, USA: Academic Press.

Received 30 October 2001; accepted 17 December 2001. 